\title{
A Sketch on Oral Mucosal Lesion Presenting in a Rural Tartiary Care Hospital in Bangladesh
}

\author{
Dr. Md. Shahidul Islam ${ }^{*}$, Dr. Mahbur Rashid Sarker ${ }^{2}$, Dr. Farkhanda Mah Jebin ${ }^{3}$, Dr. Md. Rubayet Alam Prodhan ${ }^{4}$
}

\author{
AFFILIATION: \\ 1. Dr. Md. Shahidul Islam \\ BDS, MS \\ Associate Professor \& HOD \\ Dept. of Prosthodontics, Dental Unit \\ Khwaja Yunus Ali Medical College, Sirajgonj \\ Phone\# 01819114508 \\ e-mail: smshaheen0407@yahoo.com \\ https://orcid.org/0000-0002-3457-1771 \\ 2. Dr. Mahbur Rashid Sarker \\ MBBS, MPhil \\ Professor (CC) \& HOD \\ Department of Pathology \\ Rangpur Army Medical College, Rangpur \\ 3. Dr. Farkhanda Mah Jebin \\ BDS, MPH \\ Associate Professor \& HOD \\ Dept. of Dental Public Health, Dental Unit \\ Khwaja Yunus Ali Medical College, Sirajgonj \\ 4. Dr. Md. Rubayet Alam Prodhan \\ BDS, Lecturer, \\ Department of Orthodontics and Dentofacial Orthopaedics, \\ TMSS Medical College Dental Unit, Bogra \\ Article info. \\ Received: 09 April 2021 \\ Accepted: 17 July 2021
}

Volume: Vol-11, Issue-2, October 2021

DOI: https://doi.org/10.3329/updci.v11i2.56070

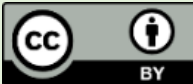

(C) Authors retain copyright and grant the journal right of first publication with the work simultaneously licensed under Creative Commons Attribution License CC - BY 4.0 that allows others to share the work with an acknowledgment of the work's authorship and initial publication in this journal.

https://creativecommons.org/licenses/by/4.0/

Publisher: Update Dental College, Dhaka, Bangladesh

Web: www.updatedentalcollege.edu.bd

E-mail: updcj@hotmail.com

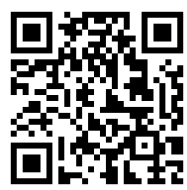

Scan QR code to see the latest issue

* Corresponding Author

Dr. Md. Shahidul Islam

BDS, MS

Associate Professor \& HOD

Dept. of Prosthodontics, Dental Unit

Khwaja Yunus Ali Medical College, Sirajgonj

Phone\# 01819114508

E-mail: smshaheen0407@yahoo.com

https://orcid.org/0000-0002-3457-1771

\section{ABSTRACT:}

Background: Oral mucosal lesion (OML) is defined as any abnormal alteration in color, surface aspect, swelling, or loss of integrity of the oral mucosal surface. Some oral mucosal lesions are benign and require no treatment but some may present with significant pathology. Several oral potential disorders frequently progress into malignancy Objective: The present study was carried out to assess the pattern of various oral cavity lesions of patients attending in a regional tertiary care hospital in northern area of Bangladesh. Materials and Methods: This prospective cross-sectional study was carried out in the Department of Dentistry in collaboration with department of Pathology of Khwaja Yunus Ali Medical College and Hospital, Sirajgonj, Bangladesh during the period of one year from December 2016 to December 2017. An elaborate schedule was prepared before undertaking the study. A total of 73 patients in the Dental OPD of the hospital presenting with oral lesion for more than 3 weeks were randomly selected. An incisional biopsy was taken from all patients and histological examinations were done. The collected data were analyzed using SPSS (V-20) and MS Excel. Results: Most common site of oral lesion is Buccal Mucosa (36.99\%), then supraglotic region (26.03\%), lower lip $6.85 \%$, ginigva $5.48 \%$, anterior palate and oral flor $4.11 \%$ each. Most of the lesion were Squamous cell carcinoma (58\%), then lichen planus, leukoplakia, inflammatory lesion, pyogenic granuloma and verrucous carcinoma, each of them was around $5 \%$ of lesion Conclusion: The epidemiological data on the prevalence of oral lesion is an important determinant in planning appropriate levels of services and further studies are required to provide accurate estimates of the treatment need in Bangladeshi population with oral lesion.

KEY WORDS: Oral lesion, Oral ulcer, Oral premalignant lesion, Oral Cancer, Tertiary care Hospital, Northern region of Bangladesh

\section{INTRODUCTION:}

An oral lesion (which includes aphthous ulcers) is an ulcer that occurs on the mucous membrane of the oral cavity. They are very common, occurring in association with many diseases and by many different mechanisms. They can be recognized by a break in the skin or mucous membrane with loss of surface tissue and the disintegration and necrosis of epithelial tissue. Oral mucosal lesion (OML) is defined as any abnormal alteration in color, surface aspect, swelling, or loss of integrity of the oral mucosal surface. ${ }^{1}$

Some oral mucosal lesions are benign and require no treatment but some may present with significant pathology. Several oral potential disorders frequently progress into malignancy. Apart from that, oral mucosal lesions have impact on mastication, swallowing and speech with symptoms of burning, irritation \& pain which may affect patient's quality of life. When there is any reactive $\&$ inflammatory condition in mouth oral mucosal biopsies are taken.Giant cell granuloma, peripheral ossifying fibroma, pyogenic granuloma, and fibrous and/or epithelial hyperplasia are some reactive lesion in the oral cavity. ${ }^{2,3}$ Hormonal changes may also affect the development of some of these lesions, including pyogenic granuloma, also called pregnancy tumor. ${ }^{4}$

The oral mucosa is also one of the most common locations for dermatomes, pigmented lesions, and viral diseases. Infection by oncogenic or no oncogenic viruses can cause several lesions in the oral mucosa. ${ }^{5,6}$ For example, human papilloma virus is responsible for papillomata's lesions, especially in the palatal 
mucosa. Immune mediated vesiculobullous diseases, including lichen planus, are also not rare in the oral mucosa and may be malignant.To understand the prevalence, distribution and risk factors of oral mucosal lesion, epidemiological studies are needed. ${ }^{7}$ Although World Health Organization recommendations to encourage more epidemiological survey of oral mucosal lesion, a very few studies has been done in this area but the results of such studies have rarely been published worldwide. Research about oral mucosal lesion is important in order to understand its extension and characteristics. ${ }^{8-10}$ Early diagnosis is the most important single factor in combating oral cancer and improving survival rate. Hence the need for this study is to determine the prevalence of $\mathrm{OML}$ in the adult patients reporting to the dental outpatient department (OPD). This study will help to elaborate the adequate management of the prevention protocol and the needed treatment for this population.

\section{MATERIALS AND METHODS:}

This prospective cross-sectional study was carried out in the Department of Dentistry in collaboration with department of Pathology of Khwaja Yunus Ali Medical College and Hospital, Sirajgonj, Bangladesh during the period of one year from December 2016 to December 2017. An elaborate schedule was prepared before undertaking the study. A total of 73 patients in the Dental OPD of the hospital presenting with oral lesion for more than 3 weeks were randomly selected. Patients' history were taken, oral examination were done, and noted accordingly on patient records. Patients in whom an intraoral examination was not possible due to inadequate mouth opening were excluded from the study. An incisional biopsy was taken from all patients and histological examinations were done. The parameters included in the study were age, gender, demographic profile, habit, clinical presentation, site and histopathological diagnosis of the lesion. All the biopsy specimens of oral cavity lesions were included in the study. Any repeat biopsy for residual lesion after therapy was excluded from the study. The collected data were analysed using MS Excel.

\section{RESULTS:}

Oral mucosal lesions are common problems in Bangladeshi population and account for a significant proportion of patients presenting to the Dental department. Due to high prevalence of use of tobacco in the form of chewing or smoking, along with use of areca nut and paan, and socio-economic context a large number of patients end up with mucosal lesions within the oral cavity. The various oral mucosal lesions commonly found in a tertiary rural hospital of northern region of Bangladesh are presented below.

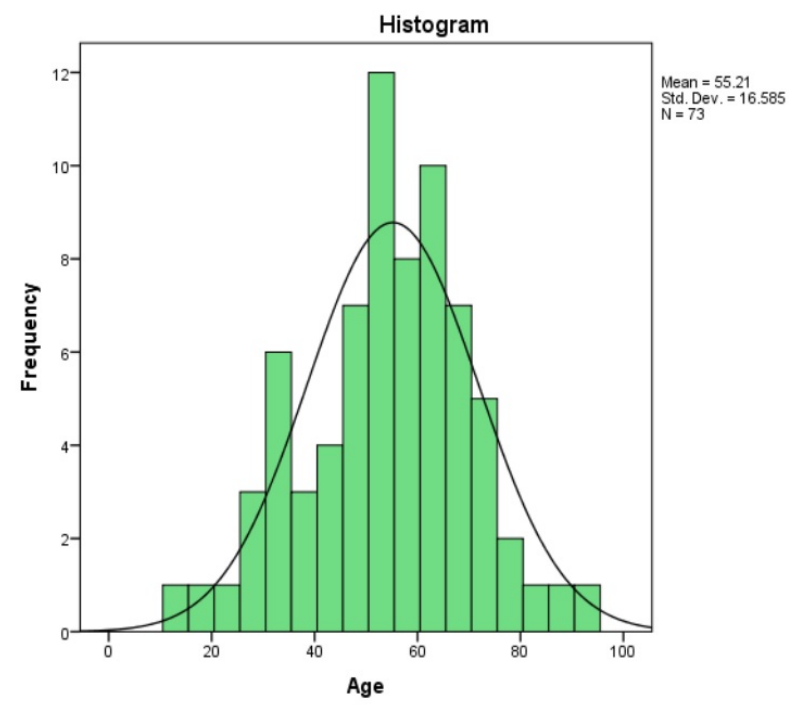

Fig 1: Distribution of patients according to age

Table I: Patients' demographic status

\begin{tabular}{|c|c|c|c|}
\hline \multicolumn{2}{|c|}{ Characteristics } & $\mathbf{N}$ & $\%$ \\
\hline \multirow{3}{*}{ Sex } & Female & 26 & 35.6 \\
\hline & Male & 47 & 64.4 \\
\hline & Total & 73 & 100.0 \\
\hline \multirow{7}{*}{ Education } & Graduate & 5 & 6.8 \\
\hline & Intermediate & 5 & 6.8 \\
\hline & Litterate & 10 & 13.7 \\
\hline & master & 7 & 9.6 \\
\hline & Primary & 20 & 27.4 \\
\hline & Secondary & 26 & 35.6 \\
\hline & Total & 73 & 100.0 \\
\hline \multirow{4}{*}{ Occupation } & HW & 41 & 56.1 \\
\hline & Service & 20 & 27.4 \\
\hline & teacher & 12 & 16.4 \\
\hline & Total & 73 & 100.0 \\
\hline \multirow[b]{4}{*}{ Socio_economic } & High & 15 & 20.5 \\
\hline & Low & 25 & 34.2 \\
\hline & medium & & \\
\hline & Medium & 33 & 45.2 \\
\hline \multirow{6}{*}{ Habit } & Betel Leaf with nu & 33 & 45.2 \\
\hline & Smookless Tobacco & 15 & 20.5 \\
\hline & Tobacco Smoking & 20 & 27.36 \\
\hline & Alcohol & 0 & 0 \\
\hline & Nothing & 5 & 6.84 \\
\hline & Total & 73 & 100.0 \\
\hline
\end{tabular}


Table II: Clinical Presentation of oral lesion

\begin{tabular}{|c|c|c|c|}
\hline \multicolumn{2}{|c|}{ Characteristics } & $\mathbf{N}$ & $\%$ \\
\hline \multirow{5}{*}{ Complaints } & No Complaints & 10 & 13.7 \\
\hline & Burning & 15 & 20.5 \\
\hline & pain & 23 & 31.5 \\
\hline & Pain with Burning & 25 & 34.2 \\
\hline & Total & 73 & 100.0 \\
\hline \multirow{4}{*}{ Mouth Opening } & Normal & 48 & 65.8 \\
\hline & & & \\
\hline & Restricted & 25 & 34.2 \\
\hline & Total & 73 & 100.0 \\
\hline \multirow[b]{4}{*}{ Oral Hygiene } & fair & 28 & 38.4 \\
\hline & good & 15 & 20.5 \\
\hline & Poor & 30 & 41.1 \\
\hline & Total & 73 & 100.0 \\
\hline \multirow{10}{*}{ Presentation } & Black pigmentation & 8 & 11.0 \\
\hline & Erosion & 13 & 17.8 \\
\hline & Nodular & 3 & 4.1 \\
\hline & Red patch & 4 & 5.5 \\
\hline & Submucous fibrosis & 3 & 4.1 \\
\hline & Swelling & 4 & 5.5 \\
\hline & Ulcer & 32 & 43.8 \\
\hline & Verrucous Ca & 3 & 4.1 \\
\hline & White patch & 3 & 4.1 \\
\hline & Total & 73 & 100.0 \\
\hline
\end{tabular}

Age of the patients ranges from 10 to 95 years; their mean \pm sd is $55.21 \pm 16.56$ (fig. 1). About one third of patients (35.60\%) are female. Thirteen point seven percent patients were literate and $6.80 \%$ patients were graduate. More than half $(56.10 \%)$ of patients were house wife, and rest are service holder and others professionals. About one third (34.20\%) patients were in low economic condition, and $20.5 \%$ were high in economic condition. About half (47.86\%) of patients were tobacco consumer either by smoking or smokeless; $45.20 \%$ patients chewed betel leaf with nut; $6.84 \%$ patients have no any oral habit (table I).

About one third of patients (34.20\%) complained paining and burning sensation in lesion site. Thirty one point five percent patients complained pain only and $20.5 \%$ patients complained only burning in lesion sit; $13.70 \%$ patients had no any complaints. About two third (65.80\%) patients' mouth opening was normal, and rests' mouth opening was restricted. Most of the patients' $(41.10 \%)$ oral hygiene is poor; and $20.50 \%$ patients have good oral hygiene. Regarding clinical presentation, the lesions are $11 \%$ black pigmentation, $17.80 \%$ mucosal erosion, ulcer $43.80 \%$ and rest are others lesion (table II).

6 I P a g e

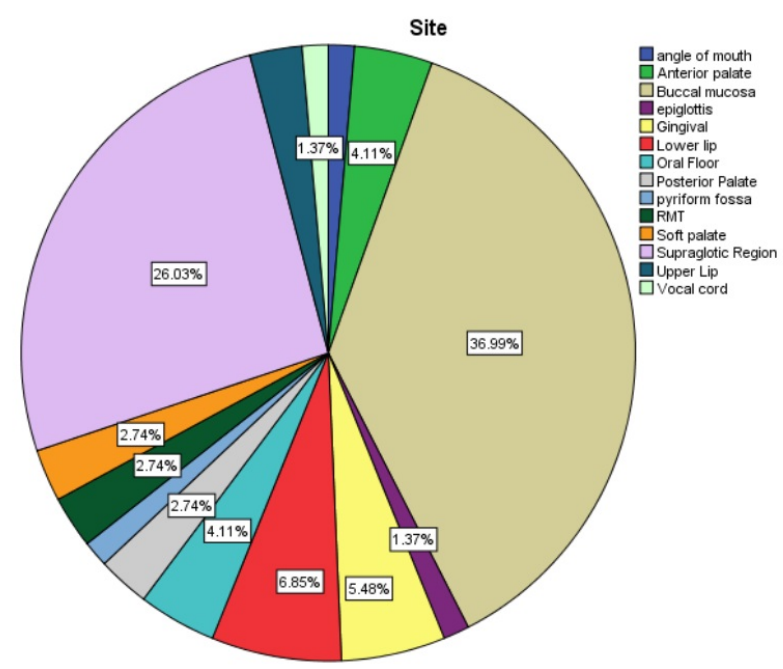

Fig. 2: Common sites of oral lesion

Most common site of oral lesion is Buccal Mucosa (36.99\%), then supraglotic region (26.03\%), lower lip 6.85\%, ginigva $5.48 \%$, anterior palate and oral flor $4.11 \%$ each (fig 2). Most of the lesion were Squamous cell carcinoma (58\%), then lichen planus, leukoplakia, inflammatory lesion, pyogenic granuloma and verrucous carcinoma, each of them was around $5 \%$ of lesion (fig 3).

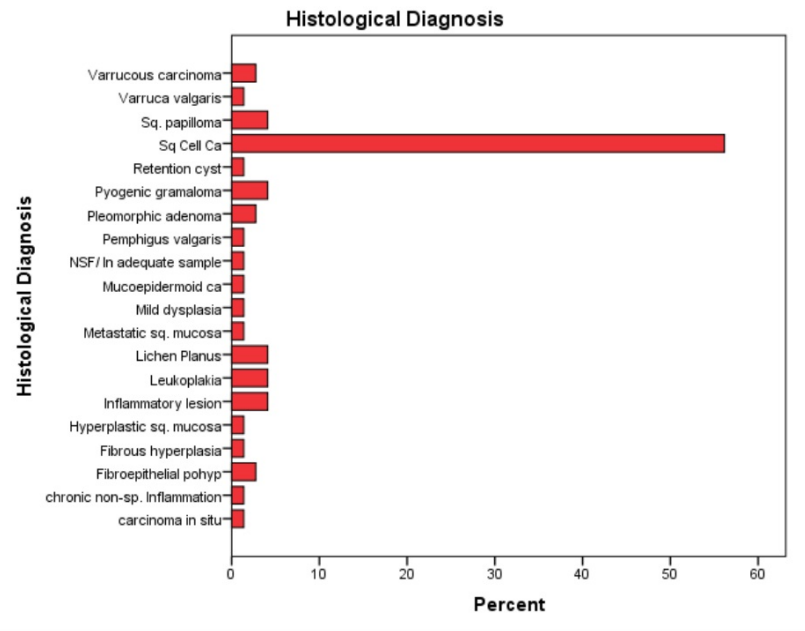

Fig 3: Diagnosis of oral lesions

DISCUSSION:

Oral depression sores are normally asymptomatic. The majority of the sores are generous with the commonest being lymphoid hyperplasia, maintenance growth, aggravation, haemangioma, fibroma and so on Among harm, squamous cell carcinoma is the most well-known pathology. Now and again beginning phases of threat may emulate considerate injuries. This prompts erroneous treatment and accordingly

Website: https://www.banglajol.info/index.php/UpDCJ 
conceivably lethal ramifications for the patient. Legitimate administration of the patient starts with a precise analysis. Histopathology is as yet the highest quality level. Various locales in the oral cavity show inclination for various kinds of injuries. The current review study was completed to evaluate the example of different oral pit injuries.

In present study, age of the patients ranges from 10 to 95 years; their mean \pm sd is $55.21 \pm 16.56$ (fig. 1). This co-relates with many studies ${ }^{11-14,}$ done in the different parts of the world. In the present study, men had oral mucosal lesions more frequently than in females, which is similar to the report by Agrawal et $a 1^{11}$ and Pudasaini and Barar. ${ }^{15}$ In contrast, previous studies by Modi et al., ${ }^{16}$ and Claudia et al., ${ }^{17}$ reported a higher incidence of oral lesions in females, probably due to more deleterious oral habits in females in their area of study. Thirteen point seven percent patients were literate and $6.80 \%$ patients were graduate. Similar results were reported by Suliman et. al, ${ }^{18}$ Aurlene et al. ${ }^{19}$ and Gheno et al. ${ }^{20}$ More than half (56.10\%) of patients were house wife, and rest are service holder and others professionals. These findings are in agreement with study of El Toum et al. ${ }^{21}$ and Babu et al. ${ }^{22}$ About one third (34.20\%) patients were in low economic condition, and $20.5 \%$ were high in economic condition. This result is consisted with the study of Aurlene et al. ${ }^{19}$ and Gheno et al. ${ }^{20}$

About half (47.86\%) of patients were tobacco consumer either by smoking or smokeless; $45.20 \%$ patients chewed betel leaf with nut; $6.84 \%$ patients have no any oral habit (table I). Thada and Pai, ${ }^{23}$ Naveed ${ }^{24}$ and Ain et al. ${ }^{25}$ reported similar findings from their study. The association between tobacco chewing in the form of gutka and cigarette smoking with pathological lesions, both pre-cancerous and cancerous has already been proven. Many studies are conducted worldwide on the epidemiology and prevalence of OML and normal physiologic variants, but there have been very few in which subjects are assigned groups according to the required treatment. Efforts to increase patient awareness of the oral effects of tobacco use and to eliminate the habit are needed to improve oral and general health. Dental professionals should advise and encourage patients to quit the use of tobacco. It is important to counsel patients who use tobacco in any form that no form of tobacco use is safe.

Oral cavity lesions are usually asymptomatic in early stage. About one third of patients (34.20\%) complained paining and burning sensation in lesion site. Thirty one point five percent patients complained pain only and $20.5 \%$ patients complained only burning in lesion sit; $13.70 \%$ patients had no any complaints. About two third (65.80\%) patients' mouth opening was normal, and rests' mouth opening was restricted. Most of the patients' $(41.10 \%)$ oral hygiene is poor; and $20.50 \%$ patients have good oral hygiene. Suliman et. al, ${ }^{18}$ reported similar symptoms in oral lesion but differs in oral hygiene in

7 I P a g e
Brazilian population. Aurlene et al. ${ }^{19}$ found similar oral hygiene in a study in India. Abdalla-Aslan et al. ${ }^{26}$ found most of the patients with oral lesion complaint of pain and burning. Pain of the oral mucosa is a common accompanying symptom of various oral mucosal lesions caused by local and systemic diseases. Pain of the oral mucosa is usually associated with a known cause of tissue damage, e.g. mucosal ulcer or erosion. Regarding clinical presentation, the lesions are $11 \%$ black pigmentation, $17.80 \%$ mucosal erosion, ulcer $43.80 \%$ and rest are others lesion (table II). Ali et el. ${ }^{27}$ published similar results from a study in Kuwait. The present study is also in agreement with Suliman et. al, ${ }^{18}$ Suvernkar et al., ${ }^{28}$ and Phookan \& Saikia. ${ }^{29}$ Most common site of oral lesion is Buccal Mucosa (36.99\%), then supraglotic region (26.03\%), lower lip 6.85\%, ginigva $5.48 \%$, anterior palate and oral flor $4.11 \%$ each (fig 2 ). This study differs from Agrawal et al. ${ }^{11}$ who found the most common site affected was tongue followed by tonsil and then the buccal mucosa. Bhatnagar et al. ${ }^{30}$ found palate is most common site followed by buccal mucosa for oral lesion in Indian population. Study by Modi et al., ${ }^{16}$ Naveed, ${ }^{24}$ and Jagtap, $^{31}$ reported buccal mucosa as the main site to be involved. Although tongue is found as most frequent site of oral lesion, the present study did not found any tongue lesion. It might be due to exclusion of tongue lesion by random selection or no case was present in study period.

Classifying oral soft tissue lesions according to their clinical appearance is an important step in the diagnostic sequence. The dental practitioner should have information about the type and severity of lesions that tend to occur in a particular population to aid in the differential diagnosis.

The finding of the wide assortment of sores that happen in the oral pit is a fundamental piece of dental practice. The commonness of OML is a significant boundary for the assessment of the oral strength of any populace, and the commonness information of these injuries is imperative for arranging oral medical care administrations. Most of the lesion were Squamous cell carcinoma (58\%), then lichen planus, leukoplakia, inflammatory lesion, pyogenic granuloma and verrucous carcinoma, each of them was around $5 \%$ of lesion (fig 3). Ali et el. ${ }^{27}$ published similar results from a study in Kuwait but they did not found any malignant lesion, this might be due to their ethnic variation, different food habit and more awareness about oral cancer. Agrawal et al. ${ }^{11}$ reported less $1 \%$ cases as squamous cell carcinoma. Ain ${ }^{25}$ and Bhatnagar et al. ${ }^{30}$ reported smooker's palate is most common oral lesion followed by leukoplakia with no malignancy in Indian population. Gheno et al. ${ }^{20}$ evaluated oral lesions during an oral cancer screening campaign in southern Brazil, they found mostly angular chelitis followed by candidiasis, no malignant cases was reported. Thada and Pai, ${ }^{23}$ Naveed ${ }^{24}$ and Goyal et al. ${ }^{32}$ found reactive lesion is most common lesion followed by leukoplakia, and oral carcinoma is found less frequently. The

Website: https://www.banglajol.info/index.php/UpDCJ 
present study provides important information about the prevalence of oral mucosal lesions among patients seeking oral care. The information presented in this study adds to our understanding of the common oral mucosal lesions occurring in the general population. Although most of these lesions are innocuous, the dentist should nevertheless be able to recognize and differentiate them from worrisome lesions, and decide on the appropriate line of treatment. Periodic continuing education programs covering oral lesions will enhance the diagnostic ability of dental practitioners.

\section{CONCLUSION:}

From the current investigation it was seen that greater part of the oral hole sores are dangerous in nature. Any injury in the oral hole ought to be biopsied to preclude harm. Some prethreatening sore was seen which has more prominent possibility for harmful change. Early conclusion of these uncommon injuries is significant from the administration perspective. Further it is recommended that individual and segment subtleties like age, sex, occupation, food propensities, other harmful propensities, religion or oral clean measures ought to be remembered for the biopsy demand frames and be appropriately filled by the alluding specialist consequently helping in recognizing the high danger gatherings. Better endeavors for expanding the mindfulness among the mass with respect to the hurtful impacts of tobacco ought to be worked out. Wellbeing experts need to assume an indispensable part in such manner.

\section{CONFLICT OF INTEREST:}

Author declared no conflict of interest

\section{Citation:}

Dr. Md. Shahidul Islam, Dr. Mahbur Rashid Sarker, Dr. Farkhanda Mah Jebin, \& Dr. Md. Rubayet Alam Prodhan. A Sketch on Oral Mucosal Lesion Presenting in a Rural Tertiary Care Hospital in Bangladesh . Update Dental College Journal, 11(2), 4-9. https://doi.org/10.3329/updcj.v11i2.56070

\section{REFERENCES:}

1. Field EA, Allan RB. Oral ulceration-aetiopathogenesis, clinical diagnosis and management in the gastrointestinal clinic. Alimentary pharmacology \& therapeutics. 2003 Nov;18(10):949-62. https://doi.org/10.1046/j.1365-2036.2003.01782.x PMid:14616160

2. Long RG, Hlousek L, Doyle JL. Oral manifestations of systemic diseases. The Mount Sinai journal of medicine, New York. 1998 Oct 1;65(56):309-15.

3. Islam NM, Bhattacharyya I, Cohen DM. Common oral manifestations of systemic disease. Otolaryngologic Clinics of North America. 2011 Feb https://doi.org/10.1016/j.otc.2010.09.006 PMid:21093628

8| P a g e
4. Gondivkar SM, Gadbail A, Chole R. Oral pregnancy tumor. Contemp Clin Dent. 2010 Jul;1(3):190-2. doi: 10.4103/0976-237X.72792. PMID: 22114415; PMCID: PMC3220110. https://doi.org/10.4103/0976-237X.72792 PMid:22114415 PMCid:PMC3220110

5. Metgud R, Astekar M, Verma M, Sharma A. Role of viruses in oral squamous cell carcinoma. Oncol Rev. 2012 Sep 14;6(2):e21. doi: 10.4081/oncol.2012.e21. PMID: 25992219; PMCID: PMC4419625. https://doi.org/10.4081/oncol.2012.e21 PMid:25992219 PMCid:PMC4419625

6. Porter S., Leão J.C., Gueiros L.A. (2017) Oral and Maxillofacial Viral Infections. In: Farah C., Balasubramaniam R., McCullough M. (eds) Contemporary Oral Medicine. Springer, Cham. https://doi.org/10.1007/978-3-319-28100-1_44-1 https://doi.org/10.1007/978-3-319-28100-1 44-1

7. Rashid, H., Lamberts, A., Diercks, G.F.H. et al. Oral Lesions in Autoimmune Bullous Diseases: An Overview of Clinical Characteristics and Diagnostic Algorithm. Am J Clin Dermatol 20, 847-861 (2019). https://doi.org/10.1007/s40257-019-00461-7 https://doi.org/10.1007/s40257-019-00461-7 PMid:31313078 PMCid:PMC6872602

8. Bhatnagar P, Rai S, Bhatnagar G, Kaur M, Goel S, Prabhat M. Prevalence study of oral mucosal lesions, mucosal variants, and treatment required for patients reporting to a dental school in North India: In accordance with WHO guidelines. J Family Community Med. 2013 Jan;20(1):41-8. doi: 10.4103/2230-8229.108183. PMID: 23723730; PMCID:

PMC3663163.

https://doi.org/10.4103/2230-8229.108183

PMid:23723730 PMCid:PMC3663163

9. Suliman, N.M., Åstrøm, A.N., Ali, R.W. et al. Oral mucosal lesions in skin diseased patients attending a dermatologic clinic: a cross-sectional study in Sudan. BMC Oral Health 11, 24 (2011). https://doi.org/10.1186/1472-6831-11-24

https://doi.org/10.1186/1472-6831-11-24

PMid:21929814 PMCid:PMC3187735

10. Rao, N.R., Villa, A., More, C.B. et al. Oral submucous fibrosis: a contemporary narrative review with a proposed inter-professional approach for an early diagnosis and clinical management. J of Otolaryngol - Head \& Neck Surg 49, 3 (2020). https://doi.org/10.1186/s40463-020-0399-7 https://doi.org/10.1186/s40463-020-0399-7

PMid:31915073 PMCid:PMC6951010

11. Agrawal R, Chauhan A, Kumar P. Spectrum of Oral Lesions in A Tertiary Care Hospital. J Clin Diagn Res. 2015 Jun;9(6):EC11-3. doi: 10.7860/JCDR/2015/13363.6121. Epub 2015 Jun 1. PMID: 26266127; PMCID: PMC4525516.

12. Mathew AL, Pai KM, Sholapurkar AA, Vengal M. The prevalence of oral mucosal lesions in patients visiting a dental school in Southern India. Indian J Dent Res 2008;19:99-103 https://doi.org/10.4103/0970-9290.40461 PMid:18445924

13. Jahanbani J, Sandvik L, Lyberg T, Ahlfors E. Evaluation of oral mucosal lesions in 598 referred Iranian patients. The open dentistry journal. 2009;3:42.

https://doi.org/10.2174/1874210600903010042 PMid:19444343 PMCid:PMC2681169

14. Saghravanian N, Mohtasham N, Ivani F, Kadeh H, Shahrakipour M. The Epidemiological Pattern of Premalignant and Malignant Epithelial Lesions in Northeast of Iran: A 43-Year Evaluation, Int J Cancer Manag. $2017 \quad ; \quad$ 10(8):e5403. doi: 10.5812/ijcm.5403. https://doi.org/10.5812/ijcm.5403 
15. Pudasaini S, Barar R. Oral cavity lesions: A study of 21 cases. Journal of Pathology of Nepal. 2011;1:49-51. https://doi.org/10.3126/jpn.v1i1.4452

16. Modi D, Laishram RS, Sharma LD, Debnath K. Pattern of oral cavity lesions in a tertiary care hospital in Manipur, India. J Med Soc. 2013;27:199-202. https://doi.org/10.4103/0972-4958.127393

17. Claudia FG, Marqués NA, Berini-Aytés L, Gay-Escoda C. Prevalence of biopsied oral lesions in a Department of Oral Surgery 2007-2009). J Clin Exp Dent. 2011;3:e73-77. https://doi.org/10.4317/jced.3.e73

18. Aurlene N, Manipal S, Prabu D, Rajmohan. Prevalence of oral mucosal lesions, dental caries, and periodontal disease among patients with systemic lupus erythematosus in a teaching hospital in Chennai, Tamil Nadu. J Family Med Prim Care 2020;9:3374-80 https://doi.org/10.4103/jfmpc.jfmpc $1263 \quad 19$

PMid:33102299 PMCid:PMC7567218

19. Suliman NM, Johannessen AC, Ali RW, Salman H, Astrøm AN. Influence of oral mucosal lesions and oral symptoms on oral health related quality of life in dermatological patients: a cross sectional study in Sudan. BMC Oral Health. 2012 Jul 8;12:19. doi: 10.1186/1472-6831-1219. PMID: 22768994; PMCID: PMC3461441. https://doi.org/10.1186/1472-6831-12-19

\section{PMid:22768994 PMCid:PMC3461441}

20. Gheno JN, Martins MA, Munerato MC, Hugo FN, SANT'ANA FILHO M, Weissheimer C, Carrard VC, Martins MD. Oral mucosal lesions and their association with sociodemographic, behavioral, and health status factors. Brazilian oral research. 2015;29(1). https://doi.org/10.1590/1807-3107BOR-2015.vol29.0093

\section{PMid:26247518}

21. El Toum S, Cassia A, Bouchi N, Kassab I. Prevalence and distribution of oral mucosal lesions by sex and age categories: A retrospective study of patients attending lebanese school of dentistry. International journal of dentistry. 2018 May 17;2018 https://doi.org/10.1155/2018/4030134

PMid:29887889 PMCid:PMC5985080

22. Babu RA, Chandrashekar P, Kumar KK, Reddy GS, Chandra KL, Rao V, Reddy B. A study on oral mucosal lesions in 3500 patients with dermatological diseases in South India. Ann Med Health Sci Res. 2014 Jul;4(Suppl 2):S84-93. doi: 10.4103/2141-9248.138019. PMID: 25184094; PMCID: PMC4145524. https://doi.org/10.4103/2141-9248.138019

PMid:25184094 PMCid:PMC4145524

23. Thada SR, Pai KM. Prevalence of habit associated oral mucosal lesions among the outpatients - A prospective cross sectional study. Int J Res Health Sci [Internet]. 2014 Jan31;2(1):263-73.

24. Naveed N. Prevalence of oral mucosal lesions and their correlation to adverse habits- A pilot study. Int J Dev Res. 2017;7:8845.

25. Ain TS, Gowhar O, Sultan S, Tangade P. Prevalence of oral mucosal lesions and associated habits in Kashmir, India. Int J Res Med Sci 2016;4:3525-30. https://doi.org/10.18203/2320-6012.ijrms20162324

26. Abdalla-Aslan R, Benoliel R, Sharav Y, Czerninski R. Characterization of pain originating from oral mucosal lesions. Oral Surg Oral Med Oral Pathol Oral Radiol. 2016 Mar;121(3):255-61. doi: 10.1016/j.oooo.2015.11.006. Epub 2015 Nov 19. PMID: 26868467. https://doi.org/10.1016/j.00oo.2015.11.006 PMid:26868467

27. Ali M, Joseph B, Sundaram D. Prevalence of oral mucosal lesions in patients of the Kuwait University Dental Center. The Saudi dental journal. 2013 Jul 1;25(3):111-8.

9| P a g e https://doi.org/10.1016/i.sdenti.2013.05.003

PMid:24179320 PMCid:PMC3809497

28. Suvernkar SV, Sadhu D, Rane M, Siddiqui NA. Clinicopathological Study of Oral Cavity Lesions in a Tertiary Care Hospital. JMSCR Volume 08 Issue $01 \quad$ January 2020;775-777 https://doi.org/10.18535/jmscr/v8i1.123

29. Phookan J, Saikia KP. A clinicopathological study of the pre-malignant conditions of oral cavity. Indian J Otolaryngol Head Neck Surg. 1998 Jul;50(3):246-9. doi: 10.1007/BF03007000. PMID: 23119427; PMCID: PMC3465058.

https://doi.org/10.1007/BF03007000

PMid:23119427 PMCid:PMC3465058

30. Bhatnagar P, Rai S, Bhatnagar G, Kaur M, Goel S, Prabhat M. Prevalence study of oral mucosal lesions, mucosal variants, and treatment required for patients reporting to a dental school in North India: In accordance with WHO guidelines. Journal of family \& community medicine. 2013 Jan;20(1):41. https://doi.org/10.4103/2230-8229.108183 PMid:23723730 PMCid:PMC3663163

31. Jagtap SV, Warhate $P$, Saini N, Jagtap SS, Chougule PG. Oral premalignant lesions: a clinicopathological study. International Surgery Journal. 2017 Sep 27;4(10):3477-81. https://doi.org/10.18203/2349-2902.isj20174520

32. Goyal R, Jadia S, Jain L, Agarawal C. A clinical study of oral mucosal lesions in patients visiting a tertiary care centre in central India. Indian Journal of Otolaryngology and Head \& Neck Surgery. 2016 Dec;68(4):413-6.

https://doi.org/10.1007/s12070-015-0868-x

PMid:27833864 PMCid:PMC5083640 